\title{
On the chromosome number in some agrieultural plants
}

\author{
Goichi Narajrma
}

(Tochigiken Normal School, Utsunomiya)

(Received Oct. 24. 1929)

The number of chromosomes in some agricultural plants was counted in pollen mother cells as well as in root tips. For pollen mother cells BeLLING's aceto-carmin was employed. The root tips were taken from pots and fixed with Flemming's median solution, and they were imbedded in paraffin, cut $16-17 \mu$ thick, and stained with HwidenHAIs's iron-alum haematoxylin. 'The results are as follows:

\footnotetext{
Reduced number

Festuca tenuifolia Hoo'T.

7 (Fig. 1)

7 (Fig. 3)

21 (Fig. 5)

Somatic number

F. pratensis GRAY.

$F$. arenaria $\mathrm{L}$.

F. duriuscula $\mathrm{L}$.

Andropogon sorghum BRoT. var. cernuus KorRs.

10 (Fig. 8)

14 (Fig. 2)

14 (Fig. 4)

42 (Fig. 6)

42 (Fig. 7)

A. sorghum Brot. var. sudanensis PrPER.

10 (Fig. 10)

20 (Fig. 9)

20 (Eig. 11)

20 (Fig. 13)

A. sorghum BRot. var. vulgaris HACK.

10 (Fig. 12)

40 (Fig. 15)

A. halepensis BRo'.

20 (Fig. 14)

28 (Fig. 17)

12 (Fig. 18)

Plantago lanceolata L.

14 (Fig. 16)

12 (F.g. 19)

18 (Fig. 20)

Setaria italica BEAUV.

Phalaris arundinaced $\mathbf{L}$.

Lolium perenne Liss.

7 (Fig. 22)

28 (Fig. 21)

LITARDIËRE (1923) reports that the haploid chromosome number of Festuca ovina, F. spadicea, $F$. varia and of $F$. elatior is 14 each. According to Levitsky (1927) the somatic chromosome number in sections Montanae, Scariosae, and Subbulbosae in Festuca is 14, and in Festuca elatior L. and $F$. ovina in the section Bovinae which is polymorphous, the same is 14-70 showing here the polyploidy. Levirsiry and Kusmina (1927) report that the diploid chromosome number of Festuca pratensis is 14 and that of $F$. duriuscula 42 . My countings in the same species coincide with these results. $F$. tenuifolia $(n=7)$ and $F$. arenaria $(n=21)$ observed by the writer are diploid and hexaploid species in the polyploid series found by Levitsky and Kusmina.
} 

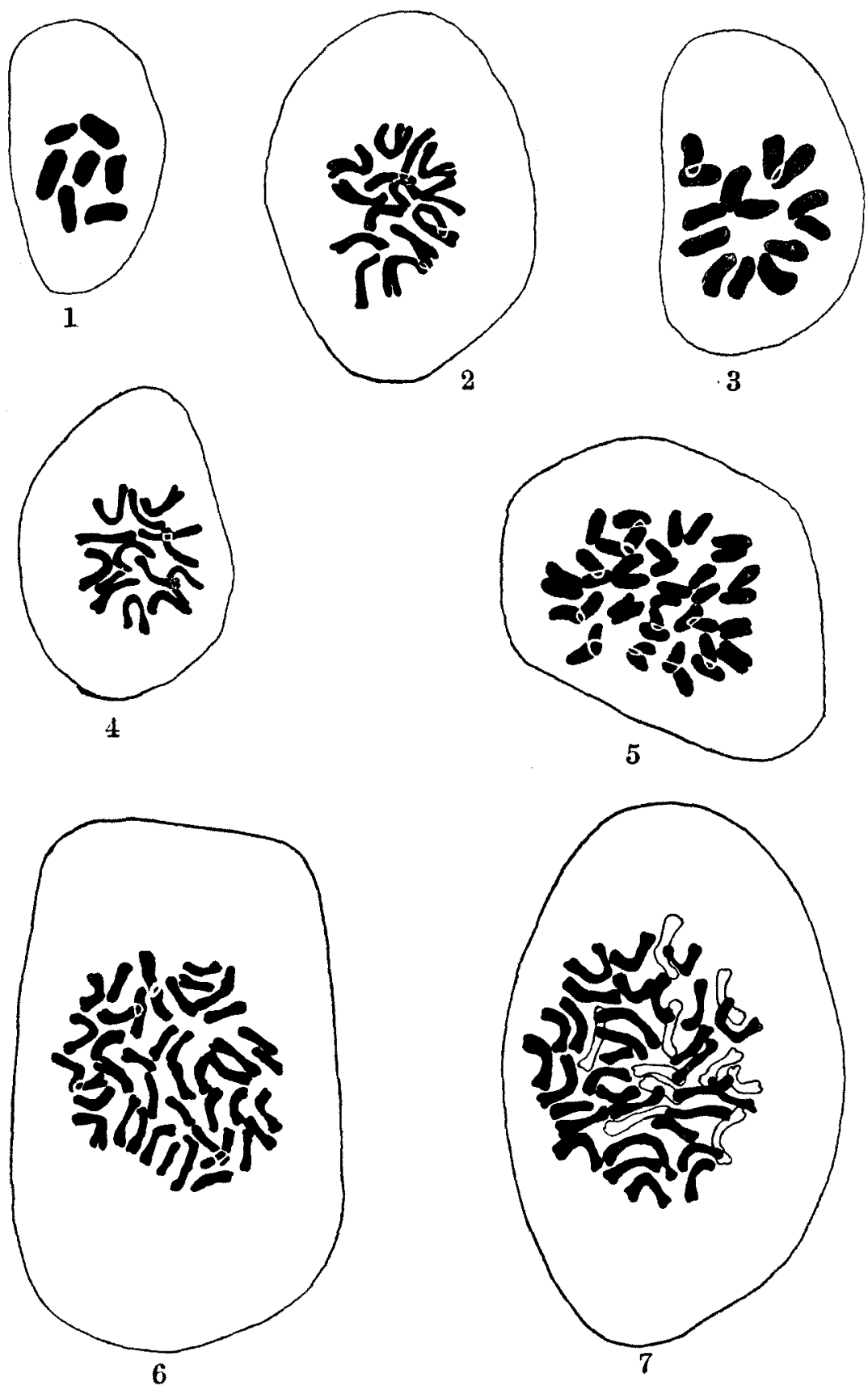

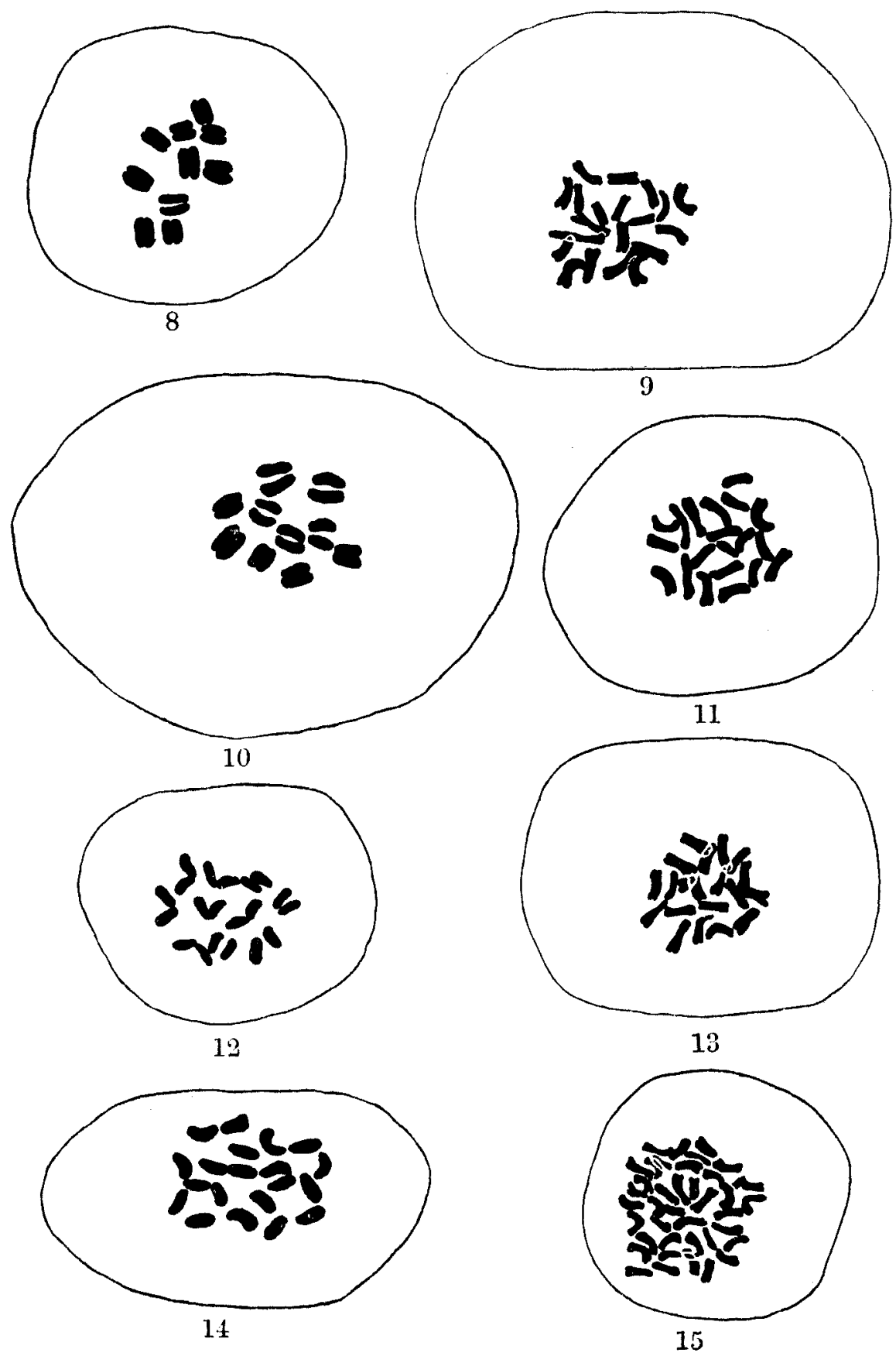

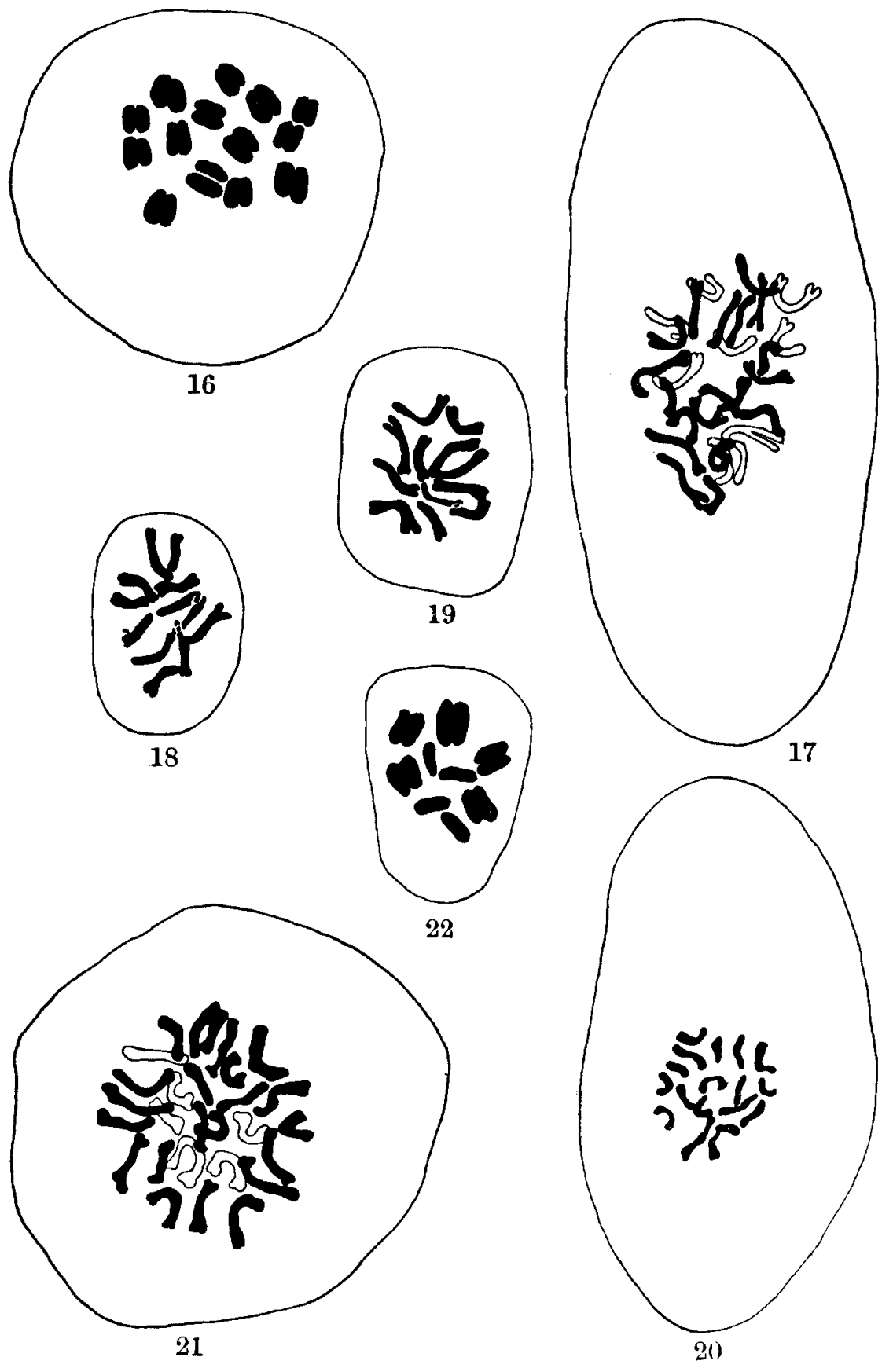
Kuwada (1919) reported that the chromosome number of Andropogon sorghum var. vulgaris and of $A$. sorghum var. obovata is $10^{\circ}$ haploid or 20 diploid. In my observation the species having 10 and 20 as the haploid number were detected, i. e., a case of tetraploidy.

According to KiHARA (1919) there is in Avena the polyploidy having 7 as the basic number. Avena flavescens observed by the writer is a tetraploid species in this series.

The somatic chromosome number of Plantago lanceolata was reported by Ňrmec (1910) to be 12 . In $P$. major the haploid number was reported by Ekstrand (1918) as 6. My countings in root tip cells of both species coincide or correspond to the results of these authors.

In closing the writer wishes to express his cordial thanks to Dr. Professor F. KaGAwA for his suggestion and guidance of this work.

\section{Literature cited}

Ekstrand, H. 1918. Zytologie und Embryologie Aer Gattung Plantago (V. M.). Svensk bot. 'Tidskr. Bd. 12. (Cited from Tischler, G.: Allgemeine Pflanzenkaryologie. Berlin. 1921-1922).

Kinara, H. 1919. Über cytologische Studien bei einigen Getreidearten. Mitteil. $\Pi$. Chromosomenzahlew und Verwandtschaftsverhältnisse unter Alena-Arten. Bot. Mag. Tolzyo, Vol. 33.

Kuwad, Y. 1919. Die Chromosomenzahl von Zea Mays L. Journ. of Sci., Imp. Univ. Tokyo. Vol. 39.

LevitkKy, G. A. 1927. Zur systematisrhen Karyologie der Gattung Festuca. Verhandl. V. intern. Kongr. Vererb.-wiss. Berlin. 1927.

Levitsik, G. A and Kusmina, N. H. 1927. Karyological investigations on the systematics and phylogenetics of genus Festuca. Bull. of. Appl. Bot. of Gen. and Pl. Br. Vol. 17. No. 3. Teningrad.

Jitardiske, R. de. 1923. Bull. Soc. Bot. France. (Cited from Tischeme, G.: Pflanzliche Chromosomen-Zablers. Tabulae Biologicat, Ba. 4. 1927).

N.̌nıc, 13. 1910. Das Problem der Befruchtungsvorgänge und andere zytologische Frugen. Berlin.

\section{Explanation of Figures}

All fignres are driwn by the aid of ABbs's camera using Lnitz $\frac{1}{12}$ oil immersion and $\times 15$ or $\times 10$ periplant ocular.

Meiotic figures are of metaphas: or early anaphase of the first division.

Magnificntion is $\times 2130$ for somatic, and $\times 2140$ for meiotic figures except Figs. 1. and 5 . in both of. which the same is $\times 1870$. 